\title{
Development of Performance Assessment Instruments Through Practical Learning to Improve Science Process Skills
}

\author{
Elfrida $^{1}$, Nursamsu $^{1 *}$, Raja Novi Ariska ${ }^{1}$ \\ ${ }^{1}$ Biology Education Department, Universitas Samudra, Langsa, Indonesia
}

\section{DOI: $10.29303 /$ ippipa.v7iSpecialIssue.867}

\section{Article Info}

Received: August 9th, 2021

Revised: November 22nd, 2021

Accepted: November 26th 2021

\begin{abstract}
Basic Biology subjects are integrated between theory and practicum. Practical learning is an essential way that teachers can take to improve students' science process skills, so a valid instrument is needed to measure it. The objective of this study is to produce a valid performance assessment instrument in practical learning; a student worksheet in practical learning; the improvement of science process skills; and teacher response. The type of research is referring to model of 4 -D. The subject of research is composed of the students in the odd semester academic year 2021-2022 at SMA Muhammadiyah Langsa. Instruments of research consist of validation sheet, student worksheet, observation sheet, questionnaire. The findings show validity score is $84 \%$ (good category); student worksheet in practical learning is $43 \%$ (very good category); there is the improvement of students science process skills before and after the practical learning, which shows by $\mathrm{N}$-gain value of $0.64 \%$ (high category); and teacher response to developed performance assessment instrument is $83 \%$ (very practical category).
\end{abstract}

Keywords: Development; Performance Assessment Instrument; Practical Learning

Citation: Elfrida, E., Nursamsu, N., \& Ariska, R. N. (2021). Development of Performance Assessment Instruments Through Practical Learning to Improve Science Process Skills. Jurnal Penelitian Pendidikan IPA, 7(SpecialIssue), 96-103. https://doi.org/10.29303/jppipa.v7iSpecialIssue.867

\section{Introduction}

Biology subjects in learning activities cannot be separated from understanding the concept so an assessment of student performance during practicum is required (Basri et al, 2017). The most difficult subjects in Biology are plant taxonomy, genetics, and plant physiology since more and deep analysis should take to mastery the concepts. Biology is composed of complex and fascinating things including the concepts, events, and processes so the explanation from the teacher or lecturing learning models is unable to cover students' nature of learning, whereas practical learning is very suited to meet students' needs of learning science. Practical learning is part of the learning activities carried out during special hours in the laboratory and integrated with science lessons (Hidayah, 2017). In addition, practical learning is used to boost the students' deeper understanding and develop students' process skills (Puspita et al in Asiah et al, 2017). Learning through practicum will stimulate students to analyze a concept by investigating problems (Jamaludin, 2017). Therefore, practical learning can increase student learning motivation and student skills (Suryaningsih, 2017). The most important aspect in practicum assessment is the psychomotor aspect which includes preparing tools and materials, conducting experiments, and post practicum activities in the form of performance (Tamsil et al, 2019).

The implementation of practical learning is inseparable from science process skills, where science process skills begin with an observation. The concept of science process skills is related to the opinion of Toharudin (2011) which explains that science process 
skills include skills of making observations, communicating, grouping (classification), doing measurements, making conclusions, predicting, identifying variables, identifying tabulations, identifying graphs, describe variable relationships, obtain and process data, analyze investigations, formulate hypotheses, conduct experiments.

Science Process Skills are very important for students as a provision to use the scientific method in developing science so that they can gain new knowledge or develop their existing knowledge (Afrizon et al., 2012). Science process skills are also an approach in teaching science based on what scientists found in research (Rusman, 2013).

To support practicum activities in the laboratory, a practicum guidebook has been compiled in the form of modules, and in the module, there is a practicum activity assessment format. Assessment of biology practicum activities is based on scores consisting of: (1) preparation stage, (2) implementation stage, (3) reporting stage, and (4) final practicum stage assessment (final test).

The final evaluation of the practicum should not be done with a written test, because one of the aspects developed in the practicum course is laboratory skills. To assess the ability that involves a performance, an alternative assessment is carried out. This alternative assessment can be in the form of an authentic assessment, portfolio assessment, and performance assessment.

The part of the evaluation contained in the performance assessment must be integrated with students' daily lives (Nurfitriani et al, 2018). Performance assessment in practicum activities can motivate passive students to be active and not only rely on their group because there are awards for each student (Meikapasa, 2017). Performance assessment for teachers can improve and increase the quality of learning because they know the abilities that have not been achieved by students through performance assessment (Zulfatin in Setiyana et al, 2017); Performance assessment can also foster teacher creativity in developing the assessment process in learning (Mulyani et al, 2017). In addition, performance assessment can improve the quality of learning (Usmeldi, 2016). When the assessments are correctly implemented, the results of the assessment will be appropriate to what is expected (Fadillah, 2017).

Previous research by (Windyarani et al, 2017) explains that learning by conducting assessments can improve student performance and teacher creativity. In conducting a performance assessment, it is necessary to pay attention to important aspects which students should have during the activities. Normally, students' performance skills are not too varied and can still be reached by using a rating scale (Basri, 2017). Based on this explanation, performance assessment is needed by teachers, especially in practicum activities so all students could be actively engaged in the learning process.

Preliminary observations made by researchers at the science laboratory of SMA Muhammadiyah Langsa show that the science laboratory already has tools or materials to support science practice and can be categorized as complete, but the problem is that most science teachers, especially teachers in the field of biology, only rely on student's worksheet with simple and inadequate assessment tools in practical activities. Whereas in measuring students' psychomotor abilities, it is not possible to use incomplete assessments because the learning concept in the 2013 curriculum (KI4) emphasizes the process of assessing student performance. The teacher's lack of knowledge in compiling the correct performance assessment instrument causes the results obtained to be unclear. As a way to provide better and fair results, the teacher must be able to conduct direct assessments and use valid, practical, and effective instruments.

Based on the previous explanation, the researcher will conduct research on the Development of Performance Assessment Through Practical Learning to Improve Process Skills at SMA Muhammadiyah Langsa.

\section{Method}

This type of research refers to the 4-D model of Thiagarajan, Semmel \& Semmel (1974). The 4-D model was chosen based on the consideration that this model is clearer, more complete, directed, structured, and systematic. This model consists of 4 stages, namely: define, design, develop, and disseminate. The dissemination stage has not been carried out in this study because that stage will be included by researchers in further research. The product developed in this research is a performance assessment instrument in practicum learning with procedures and development including (1) the definition stage, namely (a) problem analysis, which includes; teacher interviews in the field of study, field observations, and analyzing the lesson plans for Biology subjects. (b) Competency analysis. (c) Analysis of the scope of topics/materials that students must achieve. (d) Identification of problems, namely analyzing the presence or absence of authentic problems used in teaching science class practicum at SMA Muhammadiyah Langsa. (2) The design stage is to design a performance assessment instrument which starts from the preparation of tests, media selection, format selection, and initial design. (3) The 
development stage, the activities at this stage are: (a) validation as a follow-up result from the design stage. Validation is done by providing an assessment sheet of performance assessment instruments to validators who have competence in the field of Biology Education. (b) Revisions are made to improve the results of the assessment by the validator. (c) Small-scale test, which is an activity to test the readability of the practicum instructions that have been prepared. A total of $20 \%$ of students who have taken Biology subjects, especially Basic practicum, are used as trial respondents (small scale). (d) Large-scale test, which is an activity that aims to re-examine the usability of the practicum learning performance assessment instrument on a larger number of students. The number of students who acted as samples in the large-scale test was $100 \%$ of the students taking Biology subjects.

The research subjects used 20 students who took the Biology subject in the odd semester of 2021-2022 academic year. The research was conducted at SMA Muhammadiyah Langsa. The study was carried out from April to October 2019. The research instruments consisted of: (1) validation sheets; (2) student worksheets on the implementation of practical learning; (3) observation sheet on the implementation of science process skills; (4) teacher's response questionnaire. Data analysis techniques include (1) validation data collected from scoring assessment sheets given to expert validators and then averaged in each aspect and used as a percentage; (2) student worksheet scores in percentage form; (3) science process skill data analyzed by $\mathrm{N}$-gain score; and (4) teacher responses were analyzed from the average score obtained on each indicator and presented in the form of a percentage.

\section{Result and Discussion}

This research was conducted to determine the process of developing a performance assessment instrument through practical learning to improve science process skills. The results of research carried out at SMA Muhammadiyah Langsa are explained below.

\section{Stage of Field Preliminary Study}

At this stage, the research team carried out observations and collected information to support the background. Moreover, the research team also observed the situation of the learning process carried out by the biology teacher in practical learning and observe the condition of the laboratory at SMA Muhammadiyah Langsa. The finding reveals the implementation of practical learning is very rarely to carried out. This is due to the limited tools and chemicals available in the laboratory. Most of the teachers (80\%) have given score to students' psychomotor activity rely on their activity in asking questions or expressing opinions, student discipline, and cooperation. About $80 \%$ of teachers stated they did not understand the performance assessment instrument and had never made it. This is due to the absence of training for teachers related to the implementation of practicum by making performance assessment instruments.

Another fact is that teachers tend to carry out practical learning only by assessing the activity of students during practicum activities, both in terms of asking questions, responding, conveying the results of discussions or opinions. The activities of students in terms of using the laboratory tools are not paid attention to by the teacher, meanwhile, the activities such as asking, responding, conveying the results of discussions or opinions are not included in psychomotor skills, but students' attitude skills.

\section{Design and Development Stage}

Based on the results of needs analysis and interviews with Biology teachers at SMA Muhammadiyah Langsa, teachers need an instrument sheet for the implementation of the practicum in the form of an assessment of students' science process skills. Data at the development stage in this study include expert validation data (material, construction, and language). The results of the expert assessment are presented in Figure 1.

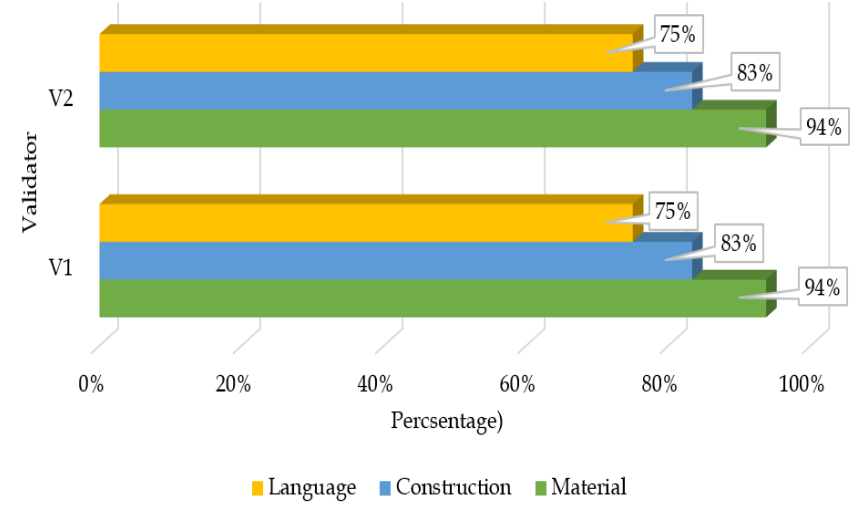

Figure 1. Expert validation of performance assessment

Aspects assessed by the validator on the performance assessment instrument include aspects of language, construction, and material. The results of the experts' validators assessment showed that the language aspect got a score of $75 \%$ (high), the construction indicator aspect scored 83\% (high) and material got a score of $94 \%$ (very high). It can be concluded that this performance assessment instrument is suitable for use in practical learning. 
The results of the research at the validation stage of the performance assessment instrument are in accordance with the results of research conducted by (Diartha, et al., 2017) that learning by applying a performance assessment instrument can improve student learning outcomes. This can be seen in the psychomotor learning outcomes of students by 57\% with a very good category. The improvement of students' creative thinking skills after the implementation of virtual laboratory learning is because students are actively stimulated to learn existing concepts. The results of the development of performance assessment instruments on the insect respiration system practicum that has been content validated indicate that the student practicum performance assessment instrument is in accordance with predetermined and valid criteria used as an assessment of student practicum performance (Nurhayati et al., 2019).

The validation of the students' practicum performance assessment instrument on the indicators for filling out the instrument and indicators of conformity with the indicators and objectives of the student practicum performance assessment showed very valid criteria which had an average of 3.50 . The next indicator is the language used in the student practicum performance assessment instrument that has valid criteria with an average of 3.33. Previous research on the language aspect has feasible and valid criteria used for practicum performance assessment with an average of 3.89 (Sukmawa et al, 2019). The suitability indicator with the rubric has valid criteria with an average of 3.00, this is in accordance with research conducted by (Basri et al., 2017) with an average of 3.5 with very valid criteria. So that the results of the overall validation of the student practicum performance assessment instrument have valid criteria with an average of 3.33 and are valid to be used as an instrument for assessing student science performance. The performance assessment at the presentation stage of experimental results for all materials was higher than in the preparation and implementation stages with the average percentage of experimental results being $88.3 \%$ (Sari et al., 2020).

Furthermore, the results of the development stage of the students' performance assessment instrument in biology practicum learning can be seen in Figure 2.

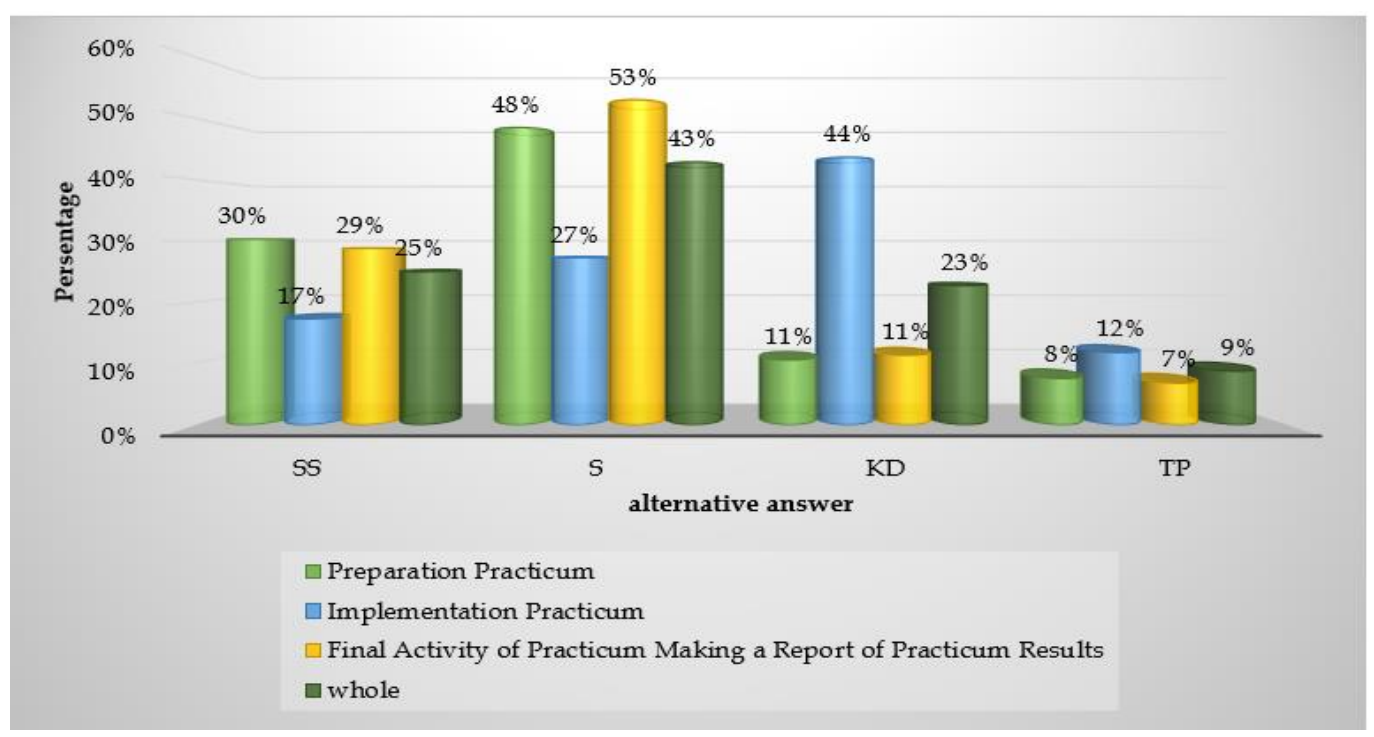

Figure 2. Students' worksheet on practical learning

The graph above shows that the assessment instrument for student practicum learning performance on student worksheets consists of 3 (three) indicators and four (4) alternative answers. The highest value is found in the alternative answers often with an average score of $43 \%$. This indicates that the practicum activities are going very well. In line with the results of Nurhidayati's research (2016) which states that practicum preparation is the first step that must be thoroughly prepared before carrying out activities, including tools and materials, practicum rooms, work safety tools, grouping practicum participants, teacher readiness in directing the course of practicum, and practical guide as a written procedure in carrying out the practicum method. This is in accordance with the research of Khamidah and Aprilia (2014), the preparation of laboratory facilities and infrastructure is an important thing that supports the implementation of practicum activities. Students' skills in preparing practical tools and materials needed in practical activities will support the implementation of biology practicum very well (Indriastuti et al., 2013). 
Related to the explanation of the results of the student worksheets in the implementation of practicum, the next step will describe the assessment of science process skills assessed by the observer in the implementation of the practicum at SMA Muhammadiyah Langsa as follows.

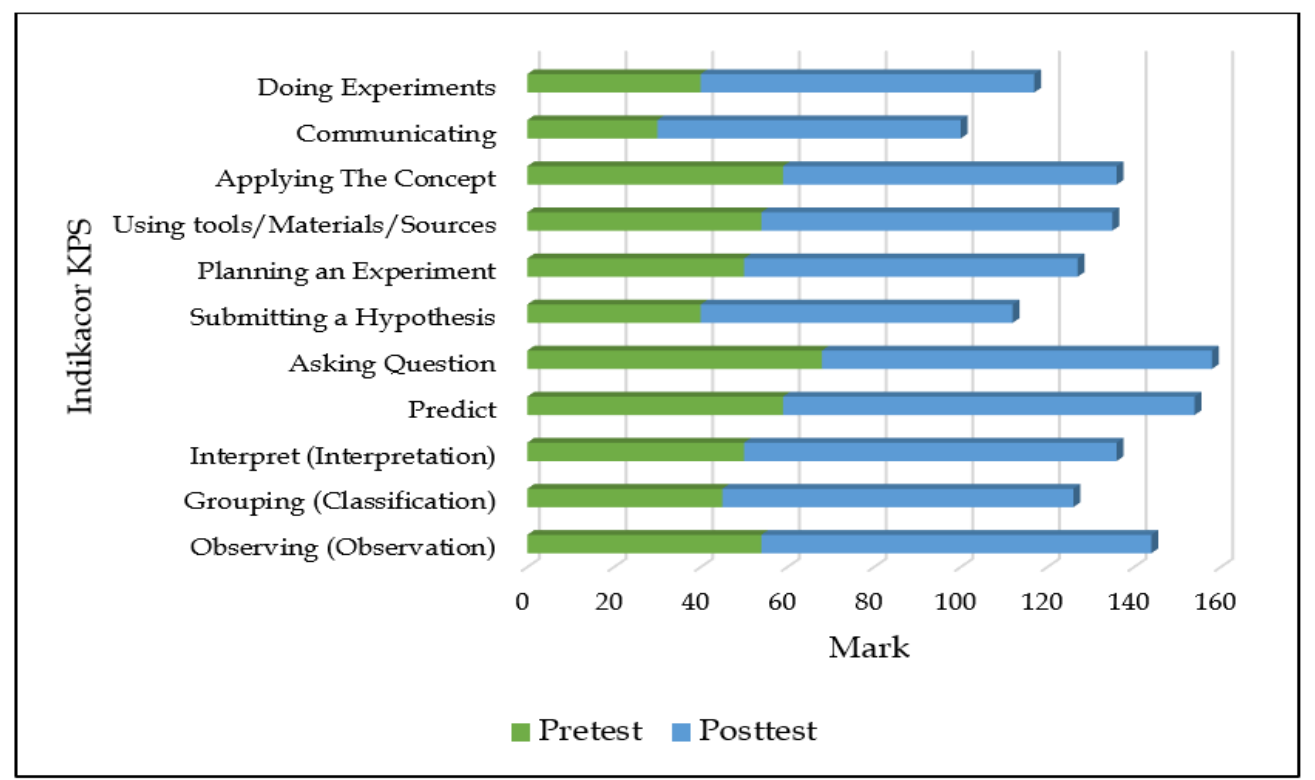

Figure 3. Science Process skills result

The graph above shows each indicator of science process skills in practical learning. The implementation of the practicum is assessed before and after the activity. Furthermore, the results of the assessment of 20 students who carried out biology practicum were calculated to measure their science process skills with the N-Gain formula. The results of the calculation of Ngain on science process skills before the implementation of practicum learning obtained a score of $49.91 \%$ with a fair category while after practicum activities a score of $81.45 \%$ was obtained and stated in a good category. It can be concluded that there was an increase in students' science process skills through the implementation of practicum with an average score of $0.64 \%$ (high category).

Students' science process skills on cell material are influenced by learning with the Problem-based learning model with the help of peer tutors (Tsaniyyah et al., 2019). Types of students' science process skills that increase include all basic skills and integrated skills. Research (Duda et al., 2019) explains that problem-based learning through practical activities can improve process skills. Prasetyo (2016) also explained that the science process skills-based microbiology practicum guide is a learning tool developed with reference to the ADDIE development model to produce valid, effective, and practical products.

The effectiveness of using a guided inquirybased science practicum guide is known to influence student activities, motivation, and learning outcomes.
(Handayani et al., 2014). Research by Widyaningrum \& Wijayanti (2019) showed that there was an increase in students' scientific performance skills through the implementation of a guided inquiry-based biochemical practicum book with an increase from cycle 1 to cycle 2 by $52.62 \%$ and the $\mathrm{N}$-gain value of 0.84 (high category).

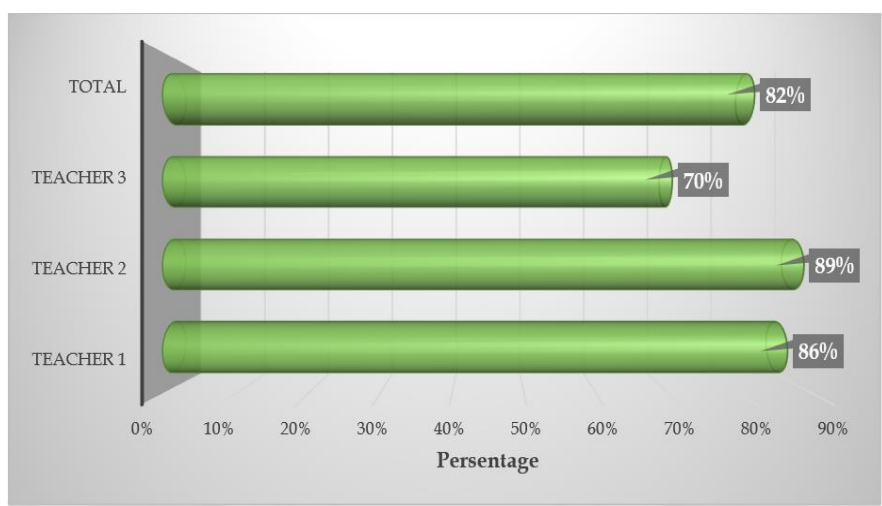

Figure 4. Teacher Responses

The results of the assessment of the teacher's response obtained a value of $82 \%$, so it was concluded that the assessment instrument was "Very Practical". This is based on the theory which states that "observers are said to have a positive response to the assessment instrument if $50 \%$ of them give a positive response to a minimum of $70 \%$ of the number of aspects asked" (Lestari, 2017).

The practicality of the performance assessment instrument is related to the research results of 
Sujarwanto (2015) where the performance assessment instrument provides convenience for teachers both in the implementation, examination, and storage of learning outcomes. The practicality of the assessment instrument is related to its ease to use when preparing, using, interpreting/obtaining results, as well save the results of the evaluation (Dimyati and Mudjiono, 2013:198; Rogier, 2014). In addition to practicality, the effectiveness of the product is also assessed in field trials. Effectiveness refers to the success of the instrument in achieving the initial goals that have been set (Degeng, 2013; Trianto, 2011). The instrument is declared effective if it succeeds in achieving the initial goal of its development. In the context of this research, the instrument is declared effective if the instrument is successfully used to record student skills in real terms, through performance assignments, projects, and portfolios from teachers.

The feasibility of the TGT (teams games tournament)-based practicum instructions equipped with a practicum performance assessment instrument in the "very good" category based on expert validation and testing on students (Ramadani et al., 2015). Application of assessment's instrument was positively responded to by students. The profile and ability to develop assessment in the affective domain was implemented with techniques and instruments in form of attitude and self-assessment that reached $90 \%$ with very good categories (exactly the same as the format of the assessment guidelines) in accordance with the 2013 curriculum and modification forms reached up to $27 \%$ categories as very less. Teachers' ability needs to be developed, instrument assessment techniques need to be improved. Data were analyzed descript (Lestari et al., 2019).

The results of the regression analysis indicate that there is a strong correlation between the use of students' worksheets to support virtual laboratory activities for knowledge and skills competencies (Hidayati and Masril, 2019). The attitude they are observations, self-assessment, assessment among students, journal and interview was answered by teachers with yes $65,62 \%$, knowledge was answered by teachers by yes $88,75 \%$ and skill were answered yes $87,75 \%$. The ability of teachers in applying authentical assessment was answered yes as many as $78,75 \%$ and the next verbally answered by teachers because of the problem in applying authentical assessments (Haqiqi et al., 2018).

\section{Conclusion}

This research produces a product in the form of developing a performance assessment instrument through practical learning to improve process skills with (1) a validity value of $84 \%$ (good category); (2) student worksheets on the implementation of practicum learning by $43 \%$ (very good category); (3) there is an increase in student process skills before and after the implementation of the practicum, indicated by an $\mathrm{N}$-gain of $0.64 \%$ (high category); and 4 ) assessment responses by teachers to the performance assessment instrument for the implementation of practicum by $83 \%$ (very Practical category).

\section{Acknowledgments}

The author would like to thank the LPPM and PM of Samudra University who have provided Funding for Superior Basic Research in 2021 with contract No. 270.26/UN54.6/PG/2021.

\section{References}

Afrizon, R., Ratnawulan, \& Fauzi, A. (2012). Peningkatan Perilaku Berkarakter dan Keterampilan Berpikir Kritis Siswa Kelas Ix Mtsn Model Padang Pada Mata Pelajaran IPA-Fisika Menggunakan Model Problem Based Instruction. Jurnal Penelitian Pembelajaran Fisika, 1, 1-16. doi: https://doi.org/10.24036/jppf.v1i1.598 [Indonesian]

Basri, Q., Syamsudduha, S., \& Taufiq, A.U. (2017). Pengembangan Penilaian Kinerja Teknik Peer Assessment pada Pembelajaran Biologi Kelas XI di MA Madani Alauddin. Jurnal Biotek. 5(2).19-36. Retrieved Form: $\quad$ http://journal.uinalauddin.ac.id/index.php/biotek/article/downl oad/4277/4069. [Indonesian]

Degeng, I.N.S. (2013). Ilmu Pembelajaran, Klasifikasi Variabel untuk Pengembangan Teori dan Penelitian. Bandung: Aras Media. [Indonesian]

Diartha, Wildan \& Muntari. (2017) Pengembangan Perangkat Penilaian Kinerja (Performance Assessment) Berbasis Kurikulum 2013 Pada Pembelajaran Kimia Kelas XI. Jurnal Penelitian Pendidikan IPA, 3(2). https://doi.org/10.29303/jppipa.v3i2.91. [Indonesian]

Dimyati., \& Mudjiono. (2013). Belajar dan Pembelajaran. Jakarta: Rineka Cipta. [Indonesian]

doi: https://doi.org/10.24036/jppf.v1i1.598.

Duda, H.J., Susilo, H., \& Newcombe, P. (2019). Enhancing different ethnicity science process skills: Problem-based learning through practicum and authentic assessment. International Journal of Instruction, 12(1):12071222. doi:10.29333/iji.2019.12177a. 
Fadillah, E.N. (2017). Pengembangan Instrumen Penilaian untuk Mengukur Keterampilan Proses Sains Siswa SMA. Didaktika Biologi. 1(2), 123-134. doi: https://doi.org/10.32502/dikbio.v1i2.770. [Indonesian]

Handayani, L.P., Farida, F., \& Anhar, A. (2014) Pengembangan buku penuntun praktikum IPA berbasis inkuiri terbimbing untuk SMP Kelas VII Semester II. Kolaboratif, 1(3):69- 76. http://ejournal.unp.ac.id/index.php/kolaboratif Larticle/view/4939. [Indonesian]

Haqiqi, Z., Ramdani, A., \& Zulkifl, L. (2018). Analisis Kemampuan Pendidik Dalam Menerapkan Penilaian Autentik Pada Mata Pelajaran Biologi Kelas X IPA SMA Di Kabupaten Lombok Timur. Jurnal Penelitian Pendidikan IPA, 4(1). https://doi.org/10.29303/jppipa.v4i1.60. [Indonesian]

Hidayah, M. (2017). Pengembangan Instrumen Penilaian Psikomotor pada Outdoor Practicum Biologi SMA. Didaktika Biologi. 1(2), 143-148. Retrieved

Form: https://jurnal.umpalembang.ac.id/dikbio/articl e/view/785. [Indonesian]

Hidayati, H., \& Masril, M. (2019). Penggunaan LKM Untuk Menunjang Kegiatan Laboratorium Virtual Fisika Inti. Jurnal Penelitian Pendidikan IPA, 5(2), 149-153. https://doi.org/10.29303/ippipa.v5i2.250. [Indonesian]

Indriastuti, Herlina, L., \& Widiyaningrum, P. 2013. Kesiapan Laboratorium Biologi dalam Menunjang Kegiatan Praktikum SMA Negeri Di Kabupaten Brebes. Journal of Biology Education 2(2): 125-132. doi: https://doi.org/10.15294/jbe.v2i2.2834 [Indonesian]

Jamaludin, D.N. (2017). Pengaruh Pembelajaran Berbasis Proyek terhadap Kemampuan Berpikir Kritis dan Sikap Ilmiah pada Materi Tumbuhan Bebiji. Jurnal Tadris Biologi. 1(1). 19-41. doi: http://journal.stainkudus.ac.id/index.php/Gen etika. [Indonesian]

Khamidah, N., \& Aprilia, N. (2014). Evaluasi Program Pelaksanaan Praktikum Biologi Kelas XI SMA Se-Kecamatan Umbulharjo Yogyakarta Semester II TahunAjaran 2013/2014. Jupemasi-Pbio 1(1): 5$8 . \quad$ Retrieved from: http://jupemasipbio.uad.ac.id. [Indonesian]

Lestari, N., Mertha, I.W., \& Kusmiyati. (2019). Profil Assessmen Autentik Pada Guru-Guru di SMP Negeri Se-Kota Mataram, Jurnal Penelitian Pendidikan IPA, 5(1). https://doi.org/10.29303/ippipa.v5i1.186.

[Indonesian]
Lestari. (2017). Pengembangan Instrumen Penilaian Praktikum pada Materi Struktur Jaringan pada Tumbuhan Siswa Kelas XI SMA Negeri 16 Makassar. Skripsi. Makassar: FTK UINAM. [Indonesian]

Meikapasa, N.W.P. (2017). Peningkatan Keterampilan Proses Sains Siswa Kelas XI Melalui Penerapan Asesmen Kinerja dalam Kegiatan Praktikum Pembelajaran Biologi Pada Siswa Kelas XI IPA 2 SMA Negeri 6 Bandung. Ganec Swara. 11(1).96101. [Indonesian]

Mulyani, L.S., Sopyan, A., \& Putra. N.M.D. (2017). Pengembangan Instrumen Penilaian Kinerja dengan Pendekatan Ilmiah pada Pembelajaran Berbasis Kegiatan Eksperimen Kalorimeter. Unnes PhysicsEducation Journal. 6(2). 16-22. doi: https://doi.org/10.15294/upej.v6i2.15971 [Indonesian]

Nurfitriani., Wulan, A.R., \& Anggraeni, S. (2018). Pengembangan Asesmen Kinerja untuk Menilai Keterampilan Proses Sains Terintegrasi Siswa pada Konsep Ekosistem. Indonesian Journal of Biology Education. 1(1), 33-38. doi: https://doi.org/10.17509/aijbe.v1i1.11454.

[Indonesian]

Nurhayati., Astuti., Ristanto., \& Miarsyah. (2019). Pengembangan Asesmen Kinerja Praktikum Sistem Respirasi Pada Serangga. Jurnal Biology Science \& Education, 8(2): 131 - 138. doi: http://dx.doi.org/10.33477/bs.v8i2.1142. [Indonesian]

Nurhidayati. (2016). Analisis Pelaksanaan Praktikum pada Pembelajaran Biologi Peserta Didik Kelas XI di SMA 7 Bandar Lampung Tahun Pelajaran 2016/2017. Skripsi, tidak dipublikasikan. Lampung: Fakultas Tarbiyah dan Keguruan Institut Agama Islam (IAIN) Raden Intan Lampung. [Indonesian]

Prasetyo, M.M. (2016). Pengembangan penuntun praktikum mikrobiologi berbasis keterampilan proses sains mahasiswa pendidikan biologi UIN Alauddin Makassar. Jurnal Biotek, 4(1):1-20. doi: https://doi.org/10.24252/ib.v4i1.1766.

[Indonesian]

Puspitasari, E., Susilo, M., \& Febrianti, N. (2019). Developing psychomotor evaluation instrument of biochemistry practicum for university students of biology education. REID (Research and Evaluation in Education), 5(1), 1-9. doi:https://doi.org/10.21831/reid.v5i1.22126

Rahmadani, Jamaluddin, \& Zulkifli, L. (2015). Pengembangan Petunjuk Praktikum Biologi Dan Instrumen Penilaian Kinerja Praktikum Berbasis Model Pembelajaran Kooperatif Dan Efektivitasnya Terhadap Kemampuan Berpikir 
Kritis Siswa SMA/MA Kelas XI. Jurnal Penelitian Pendidikan IPA, Jurnal Penelitian Pendidikan IPA, 1(2). https://doi.org/10.29303/jppipa.v1i2.13 [Indonesian]

Rusman. (2013). Model-Model Pembelajaran Mengembangkan Profesionalisme Guru. Jakarta: Raja Grafindo Persada. [Indonesian]

Sari, R., Mauliza, M., Nazar, M., \& Nahadi, N. (2020). Pelaksanaan Penilaian Kinerja Melalui Laboratorium Virtual hingga Keterampilan Berpikir Kreatif Mahasiswa. Jurnal Penelitian Pendidikan IPA, 7(1), 5-10. doi:https:/ / doi.org/10.29303/jppipa.v7i1.484. [Indonesian]

Setiyana, D., Susilowati, S.M.E., \& Pukan, K.K. (2017). Analisis Complex-Performance Assesment dalam Praktikum Biologi Siswa Kelas X di SMA Negeri 2 Pati. Journal of Biology Education. 6(1), 1-10. doi: https://doi.org/10.15294/jbe.v6i1.13952

Sugiono. (2012). Metode penelitian Kuantitatif dan RED. Bandung: Alfabeta. [Indonesian]

Sukmadinata. (2011). Metode Penelitian Penelitian. Bandung: Remaja Rosdakarya. [Indonesian]

Sukmawa, O., Rosidin, U., \& Sesunan, F. (2019). Pengembangan Instrumen Asesmen Kinerja Performance Assesment Praktikum pada Mata Pelajaran fisika di SMA. Jurnal Pendidikan Fisika. 7(1). 116-129. doi: http://dx.doi.org/10.24127/ipf.v7i1.1397. [Indonesian]

Suryaningsih, Y. (2017). Pembelajaran Berbasis Praktikum sebagai Sarana Siswa untuk Berlatih Menerapkan Keterampilan Proses Sains dalam Materi Biologi. Jurnal Bio Education. 2(2), 49-57. doi: $\quad$ http://dx.doi.org/10.31949/be.v2i2.759. [Indonesian]

Tamsil, N.M., Mustami, M.K., \& Karim, H. (2019). Pengembangan Instrumen Asesmen Kinerja Praktikum Biologi MA Pesantren Pondok Madinah Makassar. Jurnal Biology Science \& Education. 1(1).1-8. Retrieved from: http://eprints.unm.ac.id/id/eprint/12611. [Indonesian]

Toharudin. (2011). Membangun Literasi Sains Peserta Didik. Bandung, Humanlora. [Indonesian]

Trianto. (2011). Model Pembelajaran Terpadu Konsep Strategi Dan Implementasinya Dalam Kurikulum Tingkat Satuan Pendidikan. Jakarta: Bumi Aksara. [Indonesian]

Tsaniyyah, D., Marianti, A., \& Isnaeni, W. (2019). Keterampilan proses sains siswa pada pembelajaran materi sel dengan model problem base learning berbantuan tutor sebaya. Phenomenon: Jurnal Pendidikan MIPA, 9(1): 21-
35. doi:

https://doi.org/10.21580/phen.2019.9.1.3229. [Indonesian]

Usmeldi, U. (2016). The Development Of ResearchBased Physics Learning Model With Scientific Approach to Develop Students' Scientific Processing Skill. Jurnal Pendidikan IPA Indonesia, 5(1), 134-139. doi:https://doi.org/10.15294/jpii.v5i1.5802 